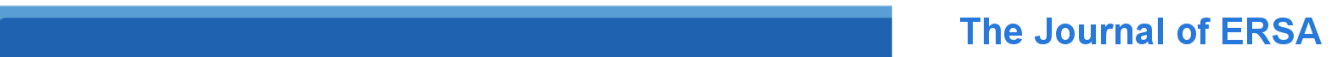 REGION

\section{Rehabilitation and Renewal of Mediterranean Structures. The Utopic Landscape of Algarve}

\author{
Carlos Bragança dos Santos ${ }^{1}$ \\ ${ }^{1}$ Universidade do Algarve, Faro, Portugal \\ Received: 29 September 2017/Accepted: 4 April 2018
}

\begin{abstract}
One of the remarkable features of Mediterranean landscapes is the terraced land frame, usually supported by dry stone walling. The terraces, property division walls, pathways and traditional paths design a network compartmentalization that defines landscape identity. The informational content, aesthetic quality, ecological and cultural values allowed by this articulated construction are particularly important at coastal zones with intense human impact. On the Algarve, the hills displayed by such structures form the backdrop of an urban-touristic system. This paper aims to interrelate ecological, aesthetic, symbolic, socio-economic and political aspects that influence the spatial distribution and image of the terraces. The values that local people may assign to their landscapes will determine the acknowledgement of the structural elements under analysis, but the role of tourists must be seriously take into account. Beyond nostalgic solutions, one must prospect the future of the dry stone walling structure into the diversity of possible solutions for a sustainable landscape development, which enhances the living part of an inseparable unit that includes the densest urbanized areas with less ecological functions. We call such a unit the urban-touristic region of Algarve and, therefore, we try to use landscape as an instrument of knowledge and acknowledgement of regional spaces.
\end{abstract}

JEL classification: Q56

Key words: Terraces, Landscape, Urban-Region, Mediterranean, Algarve

\section{Introduction}

In the Mediterranean context, the landscape is the outcome of a very long building process. "Landscapes are never completed. Rather, they are constantly being built and rebuilt through people's engagement with their inner images and with their physical environment." (Backhaus et al. 2008).

In order to understand the dynamics of a complex system such as the landscape, under a systemic approach, the first thing to do is to combine its structural aspects to reach a model of the system's functioning. However, in the case of landscape, we need to surpass the mechanist trends on approaching the biophysical and aesthetic features as merely observable and measurable objects, as if they were outside of ourselves. Thus, we will try to get closer to a mesological meaning of the landscape -landscape as a mediatory function between people and the environment (Berque 1986). 
Under this perspective, in addition to the relationship with other structural elements of different dimensions, cultural, ecological, sociopolitical, economic and spiritual, a structural feature of landscape can never be outside of individuals, as human subjects and, most of all, as a society. Therefore, the involvement of all relevant dimensions underlie the way we will seek to frame the analysis of dry stone walling structure at the barrocal ${ }^{1}$ of the Algarve region. In fact, we focus on a very representative structure modeling of the mountains and hills that fit the skeleton of many Mediterranean landscapes (Braudel 2001).

We begin with a short description of the main features of Mediterranean environment, as a distinctive broad region, in both biophysical and socio-cultural terms, in which the Algarve is included. The role of dry stone structure on terraced landscapes as hard work done by many generations that carved a regional hallmark is a very important aspect. In that sense, some functions and building aspects of dry stone walling will appear as an explanation of accumulated knowledge. However, one can only reach the real significance and the future of such distinctive structures by emphasizing the construction of landscape as a process.

Indeed, it appears obvious that the prevailing ideas of the world guide the general process of landscape construction. One cannot detach the evolution of the landscape and the actions that transform the places, from the ideas and the strategic framework derived from beliefs, either religious or philosophical. For instance, the rapid landscape changes that we are witnessing nowadays, usually leading to well-known unsustainable territories with no apparent solution, are a consequence of a prevailing dualism inherited from the Aristotelian logic.

Such an absence of solutions compels us to display positive utopias to prospect the evolution of landscape as both a common good and a place with enough biological activity to withstand large urban concentration. Therefore, we explore the idea of an urban-tourist region at the Algarve as the scenario of the various activities most likely to influence the future of the landscape structure supported by dry stone walling. The focus on a regional approach to landscape counteracts the idea of landscapes as closed entities, eventually with an optimal condition or climax state (Backhaus 2011), thus allowing its complete control. Rather, we agree that landscape evolution must comprehend constant negotiations about possible trajectories. In that sense, we present a method as a platform to facilitate communication and encourage public participation, essential to legitimize real options.

In brief, our general methodology comprehends the following steps: 1) a short prospect of the geographical environment of the Algarve's terraced landscape, enhancing perceptual features, hidden aspects and the real tensions; 2) a general description of socio-cultural relationships of the terraced landscape, building techniques, main functions, limitations and threats; 3 ) a search for alternative strategies on landscape reconstruction as a process, thus suggesting the utopia of an Algarve urban region; and 4) an exploration of the four poles method for the interpretation of landscape. Our goal is to discuss and design a process of knowledge and acknowledgment of a structure that shapes the character of the 'Algarvian' landscape and not necessarily to present finished solutions.

\section{Geographic Overview of the Algarve}

The Algarve region is located in the Gulf of Cadiz, practically in the vestibule of the western entrance of the Mediterranean Sea, known as the Hercules Columns. Mediterranean influences are present, at the climate level, in the vegetation cover and even in people's traditions. Then, one can observe many characteristic features of Mediterranean landscapes, like the terraces of barrocal hills, a distinctive factor of Algarve's landscape.

\footnotetext{
1'Barrocal' could be understood like clay (barro, in Portuguese and Spanish) plus lime (cal, idem), meaning -in real physical terms- a fine layer of clay -mostly 10 to $20 \mathrm{~cm}$ of clay- over an extensive mass of lime rock. It is a zone where water infiltration is very important and leads to a progressive dissolution of limestone; a karstic process takes place, forming big aquifers with various depths, normally reaching hundreds of meters (Costa et al. 1985). Nevertheless, according to a famous dictionary of Portuguese language (Machado 1991), the term barrocal comes from barroco meaning an isolated big rock or a place full of big rocks.
} 


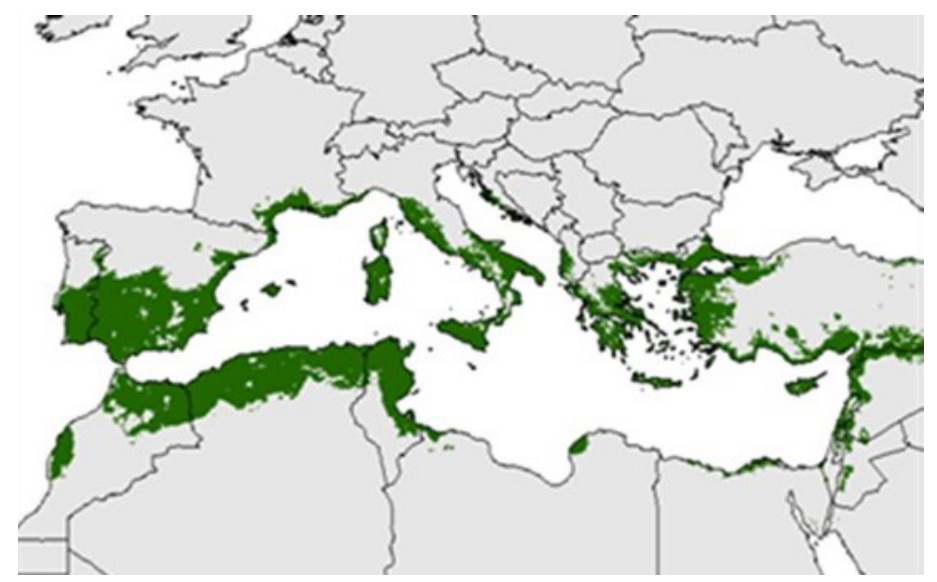

Source: Adapted from Oteros (2014)

Figure 1: Ecological niche of the potential olive tree distribution

These terraces, supported by dry stone walling structures built over generations, play a decisive role in the conservation of traditional agrosystems, not only as cultural and ecological values but also in aesthetic terms.

\subsection{The Mediterranean context}

The first issue to clarify is the integration of the Algarve in the Mediterranean geographical context. According to Forman (1995), the microclimate and the socio-cultural pattern are the two broad characteristics for defining a region. In fact, the Mediterranean climate extends a little beyond the shores of Mediterranean Sea, embracing at least the south of Iberian Peninsula. One could say that the Mediterranean region, extends until the doorway of Hercules Columns, "[the region] contrasts mightily with the Sahara area to the south, temperate Europe to the north, and a cool, dry region to the east. The Mediterranean Region is distinctive in both physical and human terms." (Forman 2008, p. 11). As the Portuguese geographer, Orlando Ribeiro used to say, the Mediterranean influence goes until the last olive tree (Figure 1).

Throughout the Mediterranean coastal regions, the omnipresence of mountains is very characteristic. "The Mediterranean space is devoured by mountains. They are present until the seafront, abusive, leaning against each other, inevitable, like the skeleton and the background of landscape." (Braudel 2001, p. 19).

It is true that the mountain ranges of the Algarve are not as visually impressive as in other Mediterranean coastal areas. The low elevation of the hills -less than 400 meters- and the progressive abandonment of traditional agricultural activities coarsen the perceptual field and the 'sense of mystery' can only be revealed when the beholder come closer. In fact, a façade of limestone hills, with an alignment roughly parallel to the coastline, is omnipresent as the backdrop of most urban concentrations. The geometric disposal of mountains shapes a sort of amphitheater opened to the sea. A second line of shale Mountains, the 'Serra', behind the limestone hills, reinforces the protection from the inconvenient cold north winds and makes the prevailing of meridional influences in all the littoral and part of the barrocal (Figure 2).

\subsection{The backdrop and the 'skeleton' of the landscape}

Despite the evident presence of a backdrop, the truth is that the strong urban growth along the coast created a considerable distance between people and their landscape, leading to several situations of loss of attractiveness and even degradation. However, under sustainable conditions, landscapes can tell their stories again in a way that people may 


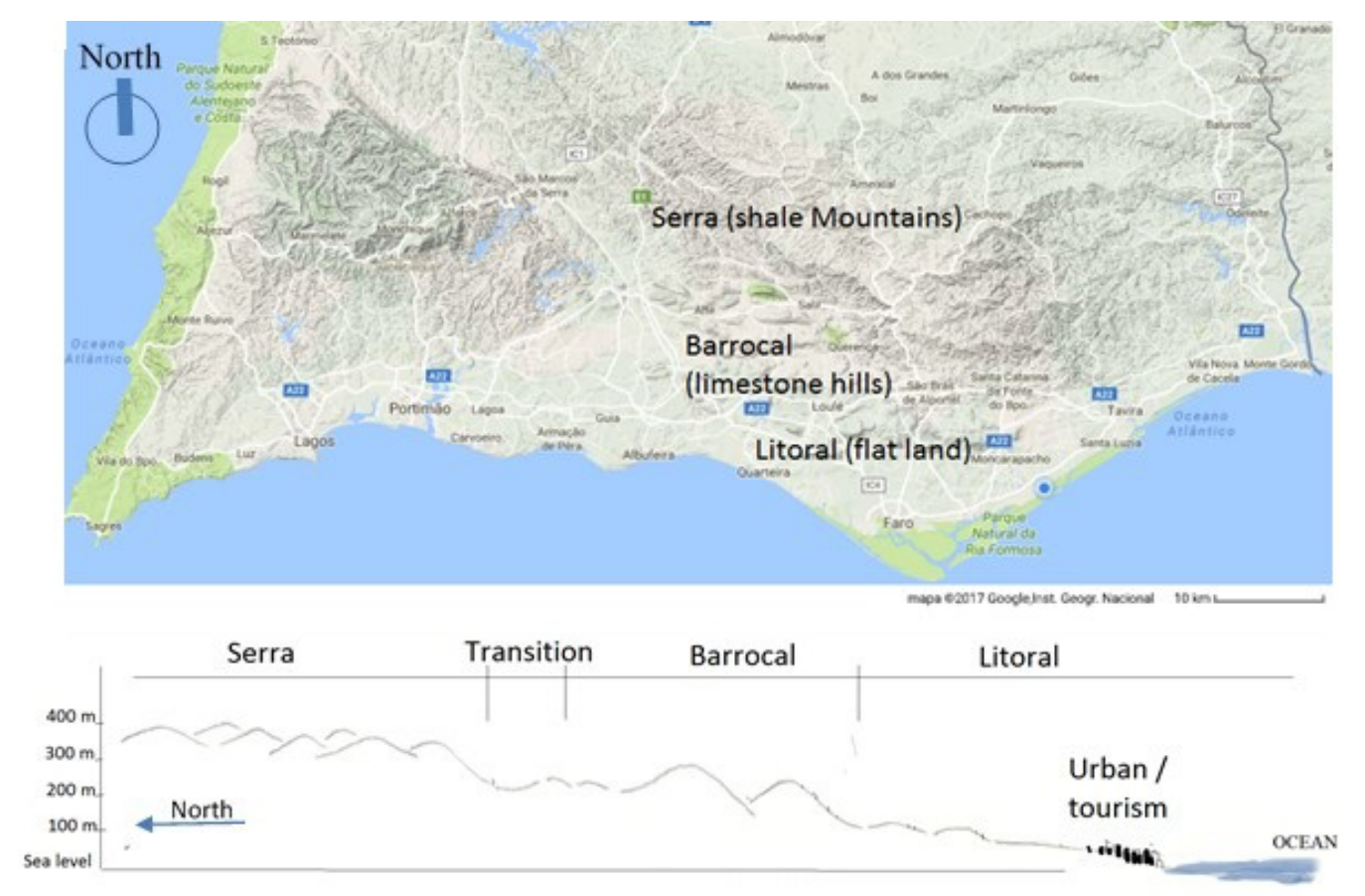

Figure 2: The different types of Algarve relief: Top: digital terrain model (adapted from google maps, 2017); Bottom: profile sketch from North to South

appreciate their narrative and poetic qualities ${ }^{2}$ again (Nohl 2001). Once the perception of many hidden aspects is not evident, the consciousness of sustainable conditions is often difficult to achieve, especially for outside observers. For that reason we empathize some concerns about critical biophysical functions and intrinsic tensions.

In fact, the barrocal exactly matches that homogeneous zone in terms of soil (chalky) and climate features, formed by the hills mentioned before. Here prevails the unirrigated orchard agrosystem, developed on terraces that constitute the hallmark of the Algarve rural countryside (Feio 1983). Much of this zone is, in fact, the background of the landscape perceived from the urban-tourist concentration along the coastline, which was spreading from the 1970s, like in many Mediterranean coastal areas.

Given that the geological bedrock of the barrocal is mostly from the Jurassic period (Figure 3), then one must take into account that the limestone dissolution generates a complex set of aquifers interlinked in the underground (Costa et al. 1985). Most of these aquifers have a high productivity and good water quality; until nowadays they were poorly exploited and provided the urban water supply up to the end of the 1990s. Then, after the year 2000, a system of dams ensured urban water supply, thus increasing the risk of eutrophication, and underground water has become more intensively used for irrigated agriculture.

Moreover, this irrigated agriculture, developed just above the largest regional aquifer, matching the northern part of Jurassic bedrock, with obvious consequences for the degradation of groundwater quality, which was partially financed by EU funds (Bragança 2006). In addition to this vital negative impact, the massive incidence of dryland transformation in irrigated land lead to a gradual substitution of part of the traditional terraced landscape. On the other hand, when soil sealing large areas of the barrocal or extracting large quantities of underground water, some disturbances can happen in the control of the salt wedge, leading to soil salinization at the littoral zone (Figure 4).

Like in other Mediterranean coastal regions, especially where the limestone relief dominates, the hydro-geological protection is undoubtedly an issue of great importance

\footnotetext{
${ }^{2}$ Nohl (2001) points out two close related aspects for landscape aesthetics: 1) the narrative aspects, related to perceptions and symptoms about the landscape functioning; 2) the poetic aspects, related to $\operatorname{mood} /$ feelings and symbols/meanings.
} 


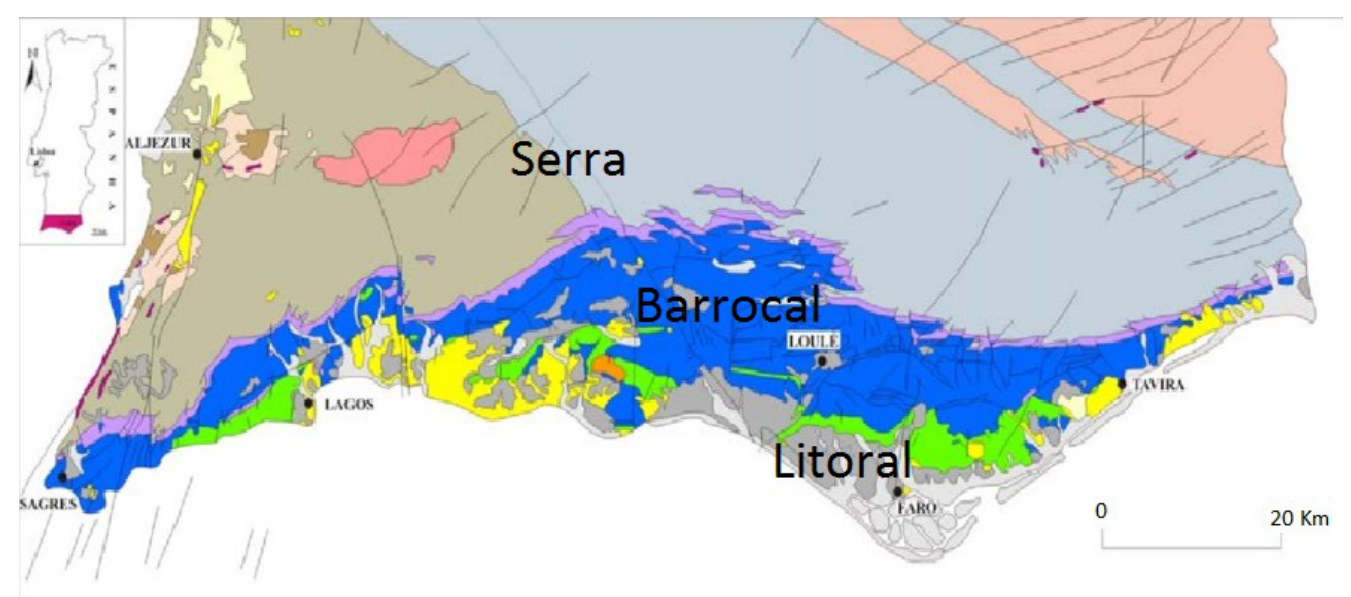

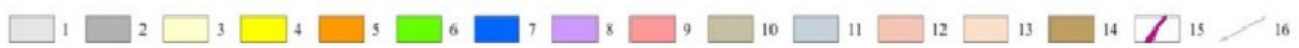

Source: Adapted from Carta Geológica de Portugal, scale 1:500 000, 1992

Notes: Typical cenozoic substratum of Litoral: 1 Holocene; 2 Pleistocene; 3 Pliocene; 4 Miocene; 5 , Paleogene. Typical mesozoic substratum of Barrocal: 6 Cretaceous; 7 Jurassic. Transition Barrocal-Serra: 8 early Jurassic-Late Triassic. Substratum of Serra: 9 Igneous intrusive massive of Monchique: 10 Vestefalian, 11 Namurian, 12 Visean, 13, Tournaisian, 14 Famennian. Complementary information: 15 reefs, 16 faults.

Figure 3: Geological map of Algarve

(Fontanari 2008, Lasanta et al. 2013). Here, favoring infiltration, mitigating the effects of torrentiality and controlling the risk of erosion, improving soil quality, are significant considerations of such protection. All these features closely links with the spatial distribution and traditional building techniques using local materials. The materials that form the dry stone walling that supports the terraces platforms come from the work of taking some stones from the previously existing relief. The resulting dry stone walling assures an effective drainage of a greatest thickness of clay soil.

Urbanites and tourists hardly realize such features, as well as the historic-cultural background and the actual range of ecological functions fulfilled by the resulting traditional agrosystems. However, from an aesthetical standpoint, these land support walls, when combined with other property separation walls and paths limitation, define an extended constructive body, which design a kind of landscape calligraphy encompassing complex alignments and rhythms. One can easily perceive a compartmentation, which sustain the ecological diversity and defines the geometry of the entire space as well.

\section{Traditional Building Structures}

In fact, one must remember that Mediterranean landscape terraces are quite resilient. Throughout their history there were cycles with periods of building and expansion followed by stability and then declining periods with abandonment, before repeating a new cycle (Guerny, Hsu 2010). Moreover, evident social factors strengthened resilience, such as the nature of collective work and social organization needed for the construction process, but also the continuous surveillance and team organizations for quick repairs in case of great damages. On the other hand, these aspects cannot be isolated from traditional techniques.

\subsection{Historical and socio-economic aspects}

The dry stone walling, apparently simple in constructive terms, represents the work of many generations, whose origin is lost in time. According to Seva et al. (2005), the dry stone walls supporting small terraces appear, at least in eastern Spain, around the XVIII century B.C., with no direct relation to agriculture, and originally serving as shelter for shepherds in transhumance practices along the mountains. Moreover, for the Bronze Age, 


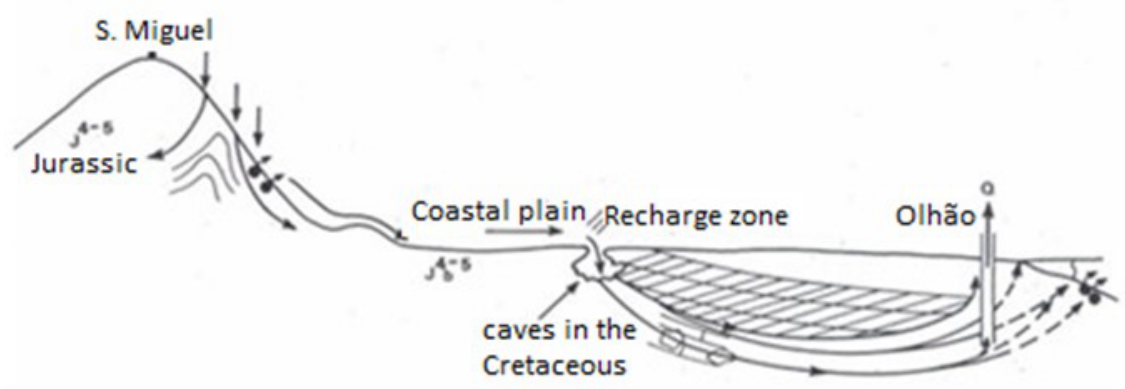

Source: Adapted from Costa et al. (1985)

Figure 4: Detail of hydraulic relations between limestone hills and littoral flat lands, northeast Faro

slope terracing is very well documented for Eastern Iberian Peninsula, mostly with the purpose of extending the household area (Asins-Velis 2006). However, the development of terracing for agricultural purposes appears in the Iberian Peninsula during the Roman times, with evidence from the first century B.C., and was further extend during the Muslim Andalusies presence, VIII-XIII centuries A.C. (Asins-Velis 2006).

In the case of the Algarve, the terraced dry orchards mainly includes fig, almond and carob trees, allowing leguminous crops under the tree crown cover, such as peas and beans, which help to incorporate nitrogen into the soil. Apart from providing food products to the populations, through the fruits and leguminous plants, carob and fig leaves are hay substitutes, which allow livestock (Feio 1983).

The development of such structures, common in many Mediterranean landscapes, for agricultural purposes mainly in the last three centuries, allowed population growth. In fact, the last period of terraced landscapes expansion occurs during 18th and 19th centuries (Guerny, Hsu 2010). At the Algarve region, however, at least in the mid-twentieth century, terraces were still in full expansion, primarily because the production of the installed fruit trees was much higher, in monetary terms, when compared to the cereal production. Around 1946-47, the production of figs, almonds, and carobs represented an important part of Portuguese exportations. The origins of such production is very ancient, already in the twelfth century A.C., the geographer and Arab botanist Edrisi, mentioned that the figs of Silves, the capital of the Algarve under the Moorish domination, were exported to all Western countries (Feio 1983).

Beyond the socioeconomic and historical interests, this kind of built agrosystem is extremely adaptive and generated new environmental equilibria, still relying on a continuous human intervention.

\subsection{Building techniques}

The construction techniques closely relates with permeability settings, allowing to redirect the water circulation and to enhance infiltration. Hence, the integrated building structure of terraces and dry stone walling define new waterways and influences land flows in a very soft manner.

Despite its apparent fragility, dry stone walling allows conditions of resistance and stability comparable to more technically modern structures like concrete walls, gabions, etc. Even from an economic point of view, dry stone retaining walls are competitive when walls are less than three meters high and even higher, when all environmental costs are accounted (Colas 2009). As for stability, this kind of walls can be included in a category of weight-walls, in which the support function is granted by the weight of the body wall that balances the landslide forces (Colas 2009, Villemus 2004).

No systematic work was found on the specific techniques used at the Algarve region, 

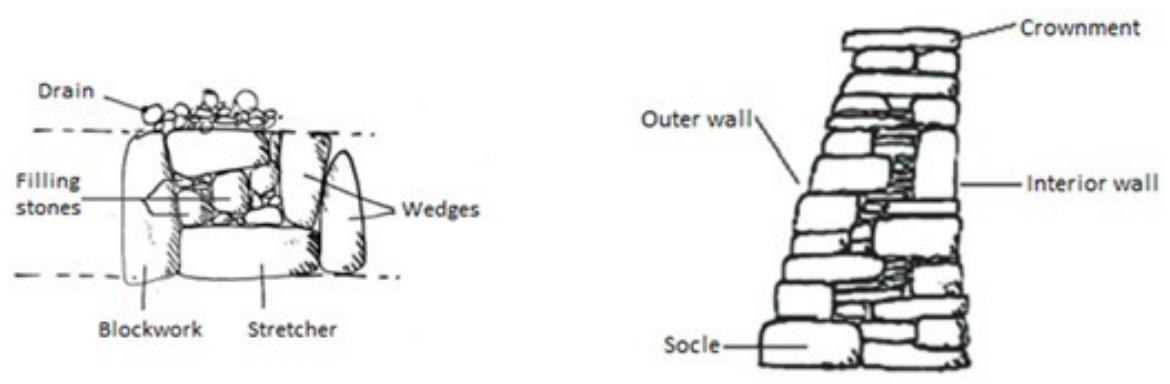

Source: Adapted from Colas (2009)

Figure 5: Building techniques. Left: Top view at the middle phase of a dry stone wall construction; Right: Cut view of a support wall

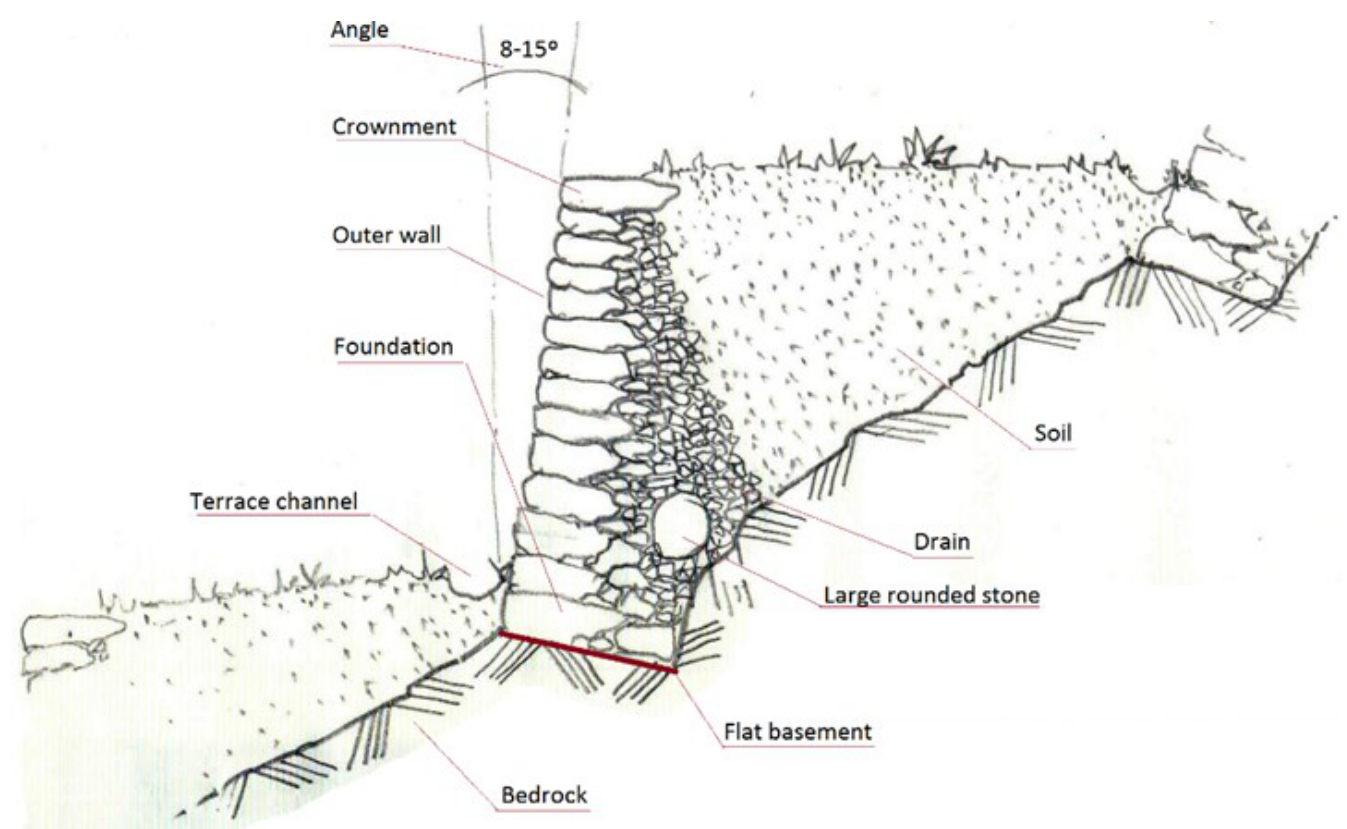

Source: Author's drawing, no scale, after Descazeaud et al. (2014) and Martini et al. (2004)

Figure 6: General scheme of a support dry stone wall

instead some field observations will be compared with documented studies for other Mediterranean regions. Although the great number of local variants, the basic technique is the placement of different types of stone in a way that they lock each other and fill interstitial spaces with thinner materials, thus improving drainage conditions (Figure 5, left).

A characteristic feature observable at the outer wall is the placement of hard materials on the basement, diminishing the size towards the top. As an indicative value but not a constructive rule, Martini et al. point to the following relation between width and height of the walls, in the case of Cinque Terre: 50 centimeters $(\mathrm{cm})$ width of wall foundation for a maximum of 1,5 meters $(\mathrm{m})$ height; about $70 \mathrm{~cm}$ width for $2-3 \mathrm{~m}$ height and $80-100 \mathrm{~cm}$ for more than $3 \mathrm{~m}$. The outer wall has an inclination whose angle (fruit in French) will depend on its height, the type of soil and subsoil, rainfall and runoff (Figure 6). Colas (2009) references $8-15^{\circ}$ for such angle, but other authors indicate $10-20^{\circ}$ (Martini et al. 2004, Villemus 2004).

As stated by Larcena (2012), the walls work like a real sanitation network, letting the water pass over a kind of drain composed by smaller stones placed just behind the main body of the wall. 


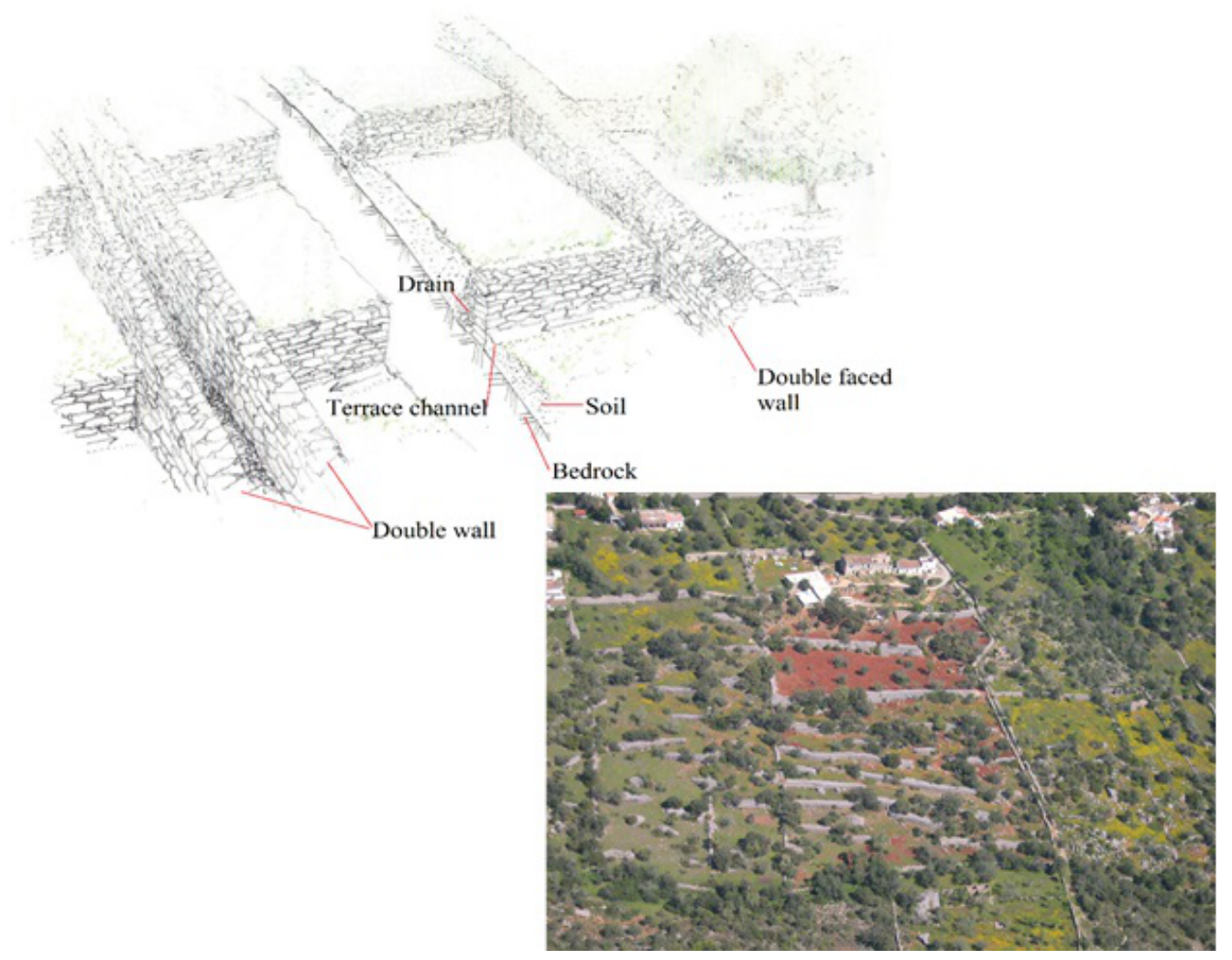

Source: Top left: Author's sketch, after Contessa (2014); no scale. Bottom right: Bragança (2006)

Figure 7: Drainage ditches. Top left: Drainage ditches in a terraced system. Bottom right: Photo near S. Brás de Alportel where double walling and other perpendicular walls are perfectly visible

The inherent fragilities due to the irregularity and the diminishing of resistance at the upper part of the wall lead to degradations over time and requires regular maintenance (Martini et al. 2004). However, drainage functions, particularly those assured at the lower part and even at the interior of the wall, guarantees the durability of most parts of the dry stone walling. For that reason, the wall basement prevents efficient drainage conditions, due to the concentration of large materials. Moreover, in some situations, the mixing of a few big rounded stones among smaller materials, just behind the basement, allows a better stability at the first row of the drainage process (Martini et al. 2004). In cases of more intensive rainfall, the definition of a terrace channel along the basement of the outer wall can happen, to help a better lateral runoff.

\subsection{Hydraulic functions}

A complex articulated set of walls shows a spatial modulation adapted to the preexisting relief modifies the natural water circulation, both in the vertical infiltration and the horizontal runoff. In fact, much of the water that infiltrates an upstairs terrace reaches the terrace downstairs, drained in the lateral sense, by a kind of micro channels carved under the walls (Larcena 2012). The definition of toe-channels is usual in areas of intense rainfall, but they are not evident on the barrocal of the Algarve region; however, some studies refer to a kind of channel with similar functions behind the crownment (Antão 2010).

Here, like in many other Mediterranean regions, the majority of walls present an alignment almost parallel to contour curves, but other wider walls cross them in a perpendicular or obliquus sense, allowing better stability and/or other functions. Such wider walls are double-faced walls, thus concentrating smaller materials inside. 


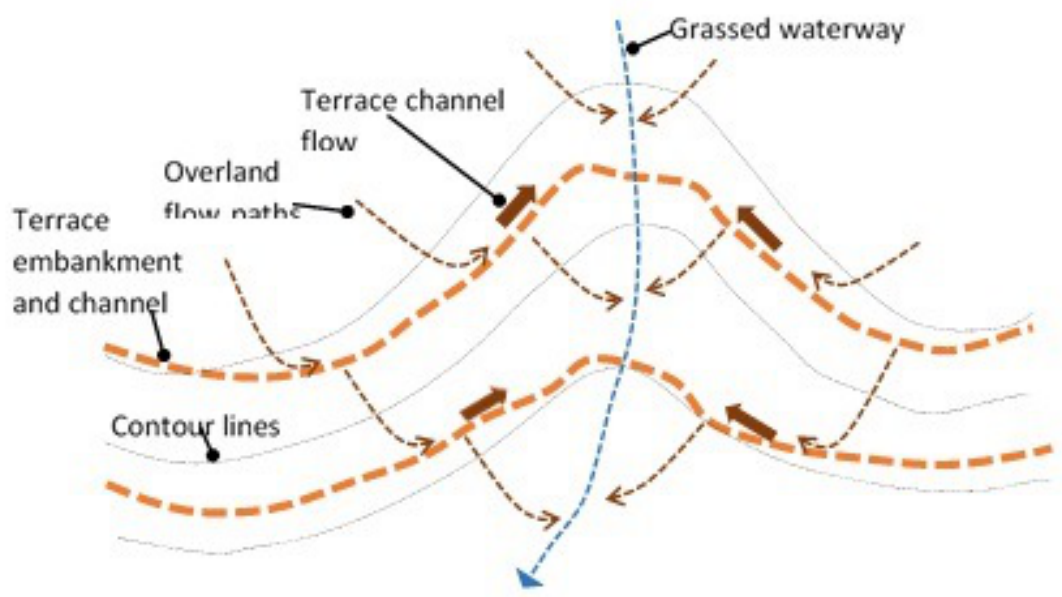

Source: Adapted from Foster (2004).

Figure 8: Scheme of the overland flows in a slope with terraced frame

Most of these walls mark the properties' boundaries, but they appear to receive and/or drain part of the lateral runoff. In some cases, such walls separate the lateral runoff. Figure 7 shows a general scheme for a case of a wider wall separating the lateral runoff. However, a double walling structure frequently helps the lateral runoff, thus mitigating the negative effects of soil erosion.

In an effective way, by receiving the water from terraces, the articulate set of drains have three functions: a) they break the torrential current in case of intense rainfall; b) they allow silt or sediment directing and c) they help to catch water that can be used for irrigation (Larcena 2012). It is true that at the barrocal infiltration is very important, but when torrential rainfall occurs, a part of the water runoff ends in little creeks or grassed waterways (Figure 8). Then, the sediment load (Foster 2004) intensifies, thus allowing the concentration of soils with better quality and moisture content along the small valleys, where there are some walls with less extensive design platforms, similar to the terrace slope embankments.

The walling is then far from a random spatial distribution. Rather, it shows a close relationship between biophysical characteristics and human intervention according to the needs of people (Reynès 2000). Figure 9 shows the adaptation of terraced structure to the topographic conditions on the barrocal. The soil deposition (Foster 2004) can be perceived along the small valley, although the shrubs do not allow a detailed view of drainage conditions. Despite the abandonment of a significant number of plots, the walling structure persists and subsistence activities are still present.

As mentioned above, the natural favorable conditions of water infiltration generates a complex set of aquifers. Less deep deposits allowed a great number of traditional wells and water springs that provided fresh water for human use and irrigation of small areas, because once it was not possible to exploit deep underground waters with traditional techniques.

We can also find some cases where clear interrelationships between walling structure and land use of valleys or other flat zones are evidently present. It is the case of small scale integrated systems of water springs, channels, water tanks for irrigation and mills, as shown in Figure 10.

\subsection{Limitations and threats}

In general terms, there is a great variety of constructive forms along all the walling structure, very well documented for most Mediterranean regions but not sufficiently systematized for the Algarve, including different techniques of stone preparing, crownment finishing, buttresses, access to platforms, combination with other rudimentary 


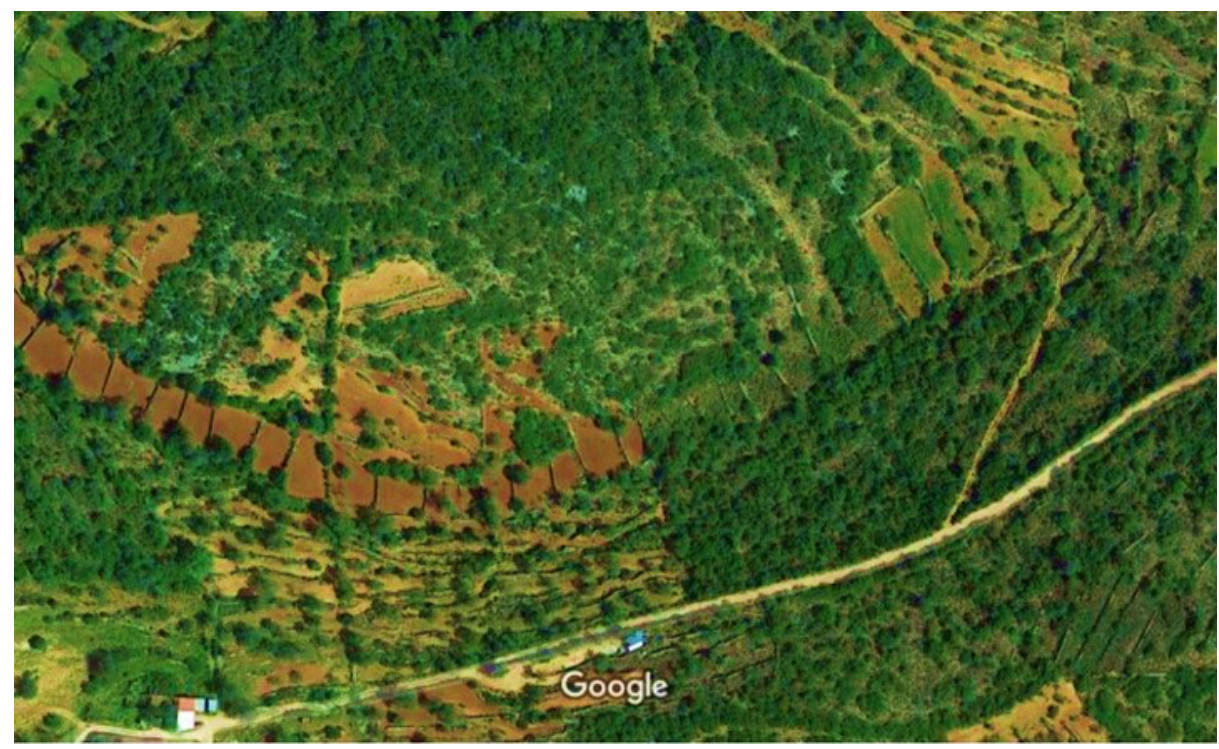

Source: Image from Google maps 2017

Figure 9: Image of a small valley near Cerro de São Miguel, Northeast Faro
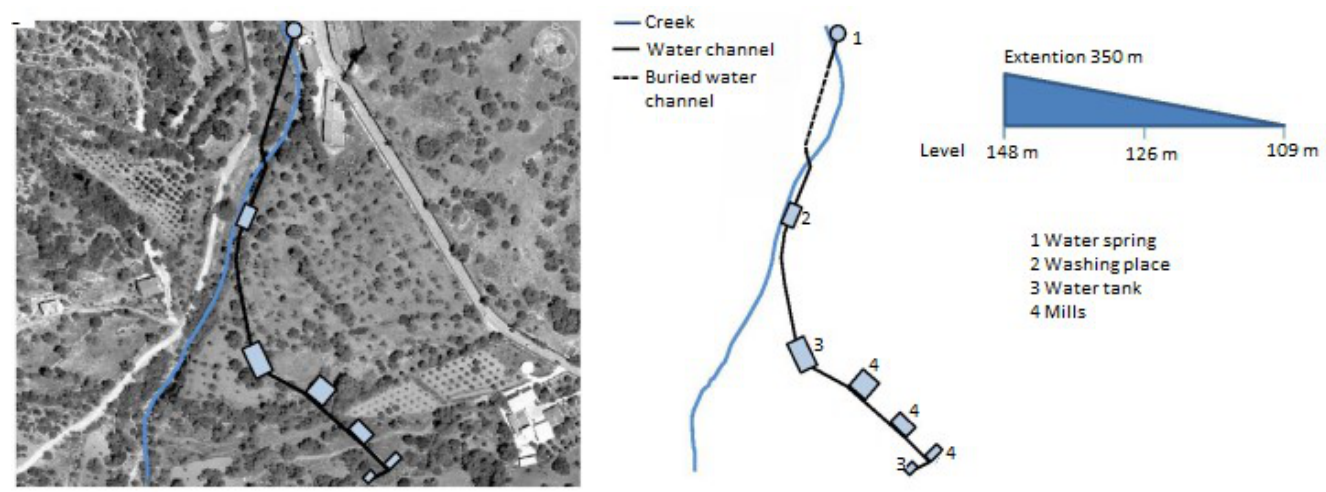

Source: Adapted from Barão (2014)

Figure 10: Hydraulic multifunctional system at Alface creek, north Faro

constructions, etc.

In addition to that, the landscape evaluation needs more specific studies about the hydraulic functioning, which are difficult to find, and about the ecological network associated to dry stone walling, including specific types of vegetation and cultural values. All such features relate closely with perceptive and symbolic aspects, it is easy to agree with Nohl's argument that "... aesthetic perception involves extracting information, knowledge and stories from the landscape, as much as possible. The more a beholder is successful at this, the greater is his emotional and expressive benefit." (Nohl 2001, p. $227)$.

As for the threats, they are very similar for all Mediterranean terraced landscapes. Following a scheme similar to that of Varotto (2008), one can identify three types of threats for the Algarve terraced landscapes: 1) lack of intervention; 2) excess of intervention and 3) creation of compensatory wilderness.

The first one relates to abandonment, the lack of stewardship by farmers ${ }^{3}$ and the

\footnotetext{
${ }^{3}$ The Algarve follows the general trends registered at the national level: loss of more than $40 \%$ workers on agriculture in the decade form 2001-2011, as pointed out by the Instituto Nacional de Estatística. The situation gets worse at the case of terraces where the access is more difficult and the size of the plots hardly allows rentable farming.
} 
disappearance of manual labor. Mechanized interventions are very difficult to develop when topographic characteristics are less advantageous. Then, the lack of intervention leads to the loss of large extensions of dry stone walling and terraces, affecting the set of complex interrelated functions. In the medium term, the domination of the garrigue ${ }^{4}$, composed by bushes and poor quality woods, will cause a biodiversity reduction and will enhance the risks of fire hazards (Guerny, Hsu 2010). The disturbance of hydrogeological equilibrium by the lack of the dry walling structure conservation will affect the stability not only of slopes but also of some areas located downstream. As for cultural values, the loss of large dry stone walling extensions deprives the knowledge of traditional techniques and environmental adaptation of people developed over centuries.

The second type, the excess of intervention, has to do with the implementation of industrial agriculture, mostly orange orchards, and, above all, with the spread housing. The expansion of orange orchards occurred mainly from 1980 to 1990, supported by EU funds. As mentioned before, this land use occupies large areas precisely over the larger regional aquifer. Ironically, the regional land management plan, legally approved in 1991, classified the area as "imperative" zone for underground water protection (Bragança 2006). This kind of action illustrates "the diktat of the productivity and the banalization of the terraced landscapes" (Varotto 2008), once the more apt areas for agriculture production, at the littoral, were progressively absorbed by tourism and urban growth. The other excess derives from the housing spread that invades the front hills of the barrocal, whose arrangement form the amphitheater facing the coastal zone. The search for good or even idyllic views result in a jealous privatization ${ }^{5}$ (Varotto 2008) of terraced landscape leading to the loss of identity and scenic attractiveness. Moreover, this contagious phenomenon has serious environmental and cultural impacts, not only by destroying or altering the dry stone walling, but also by affecting the quality and quantity of the underground water.

The 'urbanocentric' (Varotto 2008) perspective leads us to the third type of threats, the creation of compensatory wilderness. In fact, the metropolitan process of territorial organization induced by urban-tourism development, at the coastal zones, tends to spread artificialized spaces, which needs to be counterbalanced by establishing large areas for recreational use or encroachment of wilderness, normally with a positive meaning in ecological or romantic terms. As for the terraces, the concerns with protection for cultural reasons has been a common attitude between planners of some Mediterranean regions, without taking into account the complexity of its functions as a whole. It is not still the case for the Algarve, but there is a risk that the revision of the actual land management plans follow a similar practice of defining perimeters and establishing norms of conservation (Fontanari 2008).

\section{Landscape's Reconstruction}

The gap between the urban structures and the landscape is a key factor for future planning. It is an indubitable fact that, nowadays, the great majority of people live in metropolitan or pre-metropolitan ${ }^{6}$ structures. This urban concentration tends to increase the distance between people and the surrounding places, which encompass a complex set of vital functions. As mentioned above, the involvement of people where they live is essential to design the sustainable conditions that can display new narratives and enhance poetic qualities of landscape (Nohl 2001).

\footnotetext{
${ }^{4}$ The garrigue comprehends scrublands developed from the progressive destruction of former persistent leaf forests on limestone hills. At the barrocal of Algarve, some of the most common shrubs and herbs are kermes oak (Quercus coccifera), rosemary (Rosmarinus officinalis), lavender (Lavanda sp.), honeysuckle (Lonicera implexa) pistachio (Pistacia lentiscus), some species of thymus and cistus.

${ }^{5}$ Terraces are private and, at the same time, community spaces. "The private property of the lands is strongly anchored to a collective system of maintenance and management that involves the structural, viability, hydraulic and productive aspects of the same." (Varotto 2008). Urbanites buy plots for building their individual resorts like being jealous of traditional adaptation.

${ }^{6}$ There is a tendency to consider groups of municipalities as metropolitan areas, although they do not present enough population nor urban structure. For the Algarve, a region with less than 500000 resident inhabitants, the "GAMAL" -Great Metropolitan Area of Algarve- was officially created in 2004: the statutes have been published the 29 April on "Diário da República n ${ }^{\circ}$ 101- III Série". In 2008, this denomination changed to "Comunidade Intermunicipal do Algarve" and the statues published the 19 December.
} 
A central issue in this case will be the acknowledgment of specific features and values associated with the landscape terraces. "Not only did terraces have an ecologicalenvironmental role -serving to develop certain techniques of construction, to protect terrain and to offer a locus for biodiversity- but they also had a clear socio-economic importance. These latter must be understood if we are to identify the reasons why such landscapes went into decline, and thence understand how they might once again become viable economic assets within the modern world." (Fontanari 2008, p. 10). Still, a crucial aspect of the landscape's reconstruction as a value is the recognition of its aesthetic importance for people, normally associated with subjectivity. However, despite the subjective nature of values, aesthetic preferences are not completely arbitrary. "New aesthetic orientations occur, as a rule, when significant landscape changes have taken place and when there is a population group who have strong, but no necessarily aesthetic interests in the new landscape." (Nohl 2001, p. 229).

\subsection{An alternative process}

At both a collective and an individual level, three main facets must be enhanced to understand the landscape and its evolution: perception, interpretation of the displayed scenery and the objective functioning of the visualized elements. Thus, the landscape construction is a process that involves both subjectivity, including social construction, and objectivity. Berque (1986) describes trajeçtion as the intimate involvement of the subject (human) and the object (physical/biological), like being two halves of the same reality. This means that the perception of environmental features by some societies is crucial in order to define the landscape. "Trajection means that things exist according to how we grasp them by the senses, by the thoughts, by the words and by the actions" (Berque 2013, p. 63).

Such understanding, apparently 'logical', challenges the typical dualism of the scientific paradigm: on the one side is the human subject who must observe and measure any object; on the opposite side is the concrete object to measure, where what cannot be measured does not physically exists. Contrariwise, according to Berque (2013), the human subject includes a prosthesis of technical and symbolic systems, which are part of its very constitution, in an 'eco-techno-symbolic' body. Then, everything will be both objective, the ecological and the technical, as well as subjective, the symbolic. Further, as stated by Watsuji, the relationship between a society and his environment is "the structural momentum of human existence" (Watsuji 2011). One must note that the momentum has the sense given by physics of mechanics, i.e. the power rating generated by a combination of two forces, in this case, the individual subject on one side, and his/her environment as his/her other half.

Somehow, this change of perspective undermines the common notion of 'natural landscape'. In fact, the 'natural' often arises as a reference for a visible and even imaginary nature that no longer exists, or that is succumbing to the constant aggression of a society that gradually broke up its ecological prosthesis. There is an illusion of fixing a standard unit, whereby one would measure the visible reality out of ourselves, hiding the effective conditions of degradation that is actually affecting all of us. However, as Bernard Kalaora points out, "contemporary nature cannot be conceived out of society, on the contrary it is grasped to all social phenomena" (Kalaora 1998, p. 17). Under this perspective, we will highlight an accordance of "global landscape" (Telles 1998) which embraces the interlinked urban and rural areas. These are the places where more people concentrate, with all the physical, biophysical, cultural, economic, and political environments that affects their own life.

Then, once the landscape is increasingly seen as a common good (Antrop 1999), the public participation in decision-making about the landscape evolution will be crucial. To this extent, a clear communication about the aspects involved in landscape transformation, leading to understand its complexity through soft models, will be essential, as will be referred to later. 


\subsection{Historical and philosophical background}

For a better understanding of our perspective about landscape's evolution or reconstruction, we begin by a synthesis of some conceptual aspects, which regulate the meaning, the thought and the actions on landscape building in the professed Western world.

The Mediterranean environment, where Greek philosophy flourished, was the scenario of many metaphors and philosophical constructions. In the Greek world, the concept of city-region included all the space surrounding the human settlements. Such space supported and nourished the city itself, being part of the same unit that thrived as a whole. Thus, human communities depended on a space that fulfilled all their needs, not only food, lodging, but also aesthetic references, mental well-being, etc. Consequently, the space shaped by those communities, therefore being the matrix, like the mother, of the urban society, enclosed at the same time their print, like the son.

In a philosophical formulation of the world's organization, Plato in the Timaeus, proposed the term chôra to traduce metaphorically the reality of 'space - human community' relationships. He placed the term between the relative Being, genesis, which is born, lives and disappears and the absolute Being, idea, independent from time and space. Apart from the idea, the chôra feeds the genesis, which could not live without the chôra, both forming the sensible world, the kosmos. Thus, the chôra, i.e. the medium that surrounds the existent (Brisson 1998, Berque 2013), was both the one thing, the print, and its contrary, the matrix. Following Berque (2013), this was an aporia that Plato could not overcome, since he did not allow a third genus, triton allo genos, nor relative Being nor absolute Being, which he points out as the chôra.

The legacy of this aporia, which rejects the third genus, prevailed in the Aristotelian logic development and it is at the root of modern dualism with strong influences on Western thought. Indeed, this principle of 'the third excluded' still has a doubtful logical sense and influences the relationships between the human subject and his environment; individuals and society often consider their biophysical surrounds a perfect external entity. Then, according to Berque (2012), one ceases to relate the micro with the meso and the macro Kosmos, as intrinsic components of the human identity. Two classic references of modernism critics illustrate the dualistic approach: 1) in the view of Descartes thought, the environment would be considered a neutral object and 2) in Newtonian physics, an absolute object, homogeneous, isotropic and infinite (Naredo 1982). As a quick conclusion, the ontological foundations of modernism are referenced in the Timaeus.

The fact is that in modern societies, especially in metropolitan areas, where most people concentrate, the loss of a sense of Kosmos, derived from the ancient refusal of the third genus (triton allo genos), induces apprehensive 'allogeneic' conditions. Urban policies heavily exploit a landscape imagery that masks the propensity to ignore the human labor, which generated the real landscapes and direct attention to beautiful and ideal 'natures' (Donadieu 2012). From the perspective of Berque's mesological geography, the liberal capitalist economy takes advantage of the popular trend to copy the position of elites wagered on making the work invisible for society (Donadieu 2012).

Hence, we witness an individualism-based system, in which the human subject cuts the links to the medium that surrounds him, thus separating a physical/eco body from his eco-techno-symbolic entirety (Berque 1986). The loss of a human sense of the places where people dwell is a consequence of breaking such existential ties that bind people to an autonomous interpretation of the real landscape. In contrast, urban societies ends up conditioned by fétiche objects and spaces. This explains why people do not react to cities with unscaled architectures, social environments of increasing inequality, segregated and guarded urban life, unreliable food supplies, fictitious land management plans and environmental conditions constantly deteriorating (Donadieu 2012).

\subsection{Towards 'kosmic' or utopic landscapes}

It is difficult to ignore this globalized and virtualized world with no apparent way out, lacking real pathways towards more sustainable solutions. We are then compelled to agree on a philosophical 'back to basics' regarding the recuperation of a common sense of 'kosmos', now applied to actual urban structures. Such sense of 'kosmos' is the sense of 
landscape. From this perspective, we place two main questions regarding the landscape evolution: 1) how can we take a step forward? and 2) how can we discover alternative ways?

In a common sense, dreams command life and, like in many other similar situations in the history humankind, utopias can be very useful. As Donadieu (2012) notes, utopias suggest virtual and rational worlds, they are not predictions nor forecasts, they just build a virtual society without having a geographical location. This author distinguishes two types of operational utopias, which try to move from dream to reality, both pursuing the common values for wellbeing, living and thinking: the chimerical and the realistic ones. The first type of utopias rely on dogmatic beliefs, specific to dualistic views and, when achievable, usually have a high price. History, not so distant, of National Socialism or regimes inspired by dogmatic Marxism provides significant examples. The second type, the realistic utopias, with no aporias nor social dramas, pursue the access to common wealth based on solidarity and mutual respect.

As stated by Petrella, "The object of the common good is the common wealth, i.e. the set of principles, rules, institutions and resources that promote and guarantee the existence of all the members of a human community. On the intangible level, one of the elements of the common good comprises the triptych recognition-respect-tolerance in relations with the other. In material terms, the common good is structured around the right to fair access for all to food, housing, energy, education, health, transport, information, democracy and artistic expression." (Petrella 1996, p. 13). According to this author, the Welfare State, already experienced after the great crisis of 1929, designates the aspiration to the common good based on solidarity, thus being an example of a realistic utopia.

One may also look to sustainability and urban sustainability as realistic utopias, being the endpoint that we seek, but never reach (Forman 2008). However, the scale is actually one of the key issues to make a realistic utopia operational, in a way that people can have an effective participation with common goods management. The huge gap between the citizens and the decision-making centers, as well as the prevailing strategies based on the maximization of the investor's profits, back to capitalism $1.0^{7}$, are strong barriers, and block new evolutions.

The search for a proper spatial and temporal scale where we are able to cause specific changes in order to move towards a better world will then face us with what Forman (1995) calls the management paradox: "Small spaces are easily changed, but inherently unstable. Large spaces are hard to change, yet have considerable stability." (Forman 2008, p. 316). When focusing on mid-size spaces, such as landscapes and regions, one's improvement efforts achieves an effect that can be visible on the short term and can persist in the long term. Like trying to take care of our own garden, we should think, "Landscapes and regions are simply big gardens to be invested in and cared for." (Forman 2008, p. 316).

In that sense, Forman (2008) proposes the concept of urban-region, looking where best to focus efforts for an effective mesh of nature and people in and around cities. The intention is to apply the concept to the places in which more than $50 \%$ of world population currently concentrates. In the urban-region scheme, the part with less ecological functions corresponds to the hole of a donut, an empty space having several forms, and the part with highest bio-ecological potential and landscape value, corresponds to the ring forming the sugary mass of the same donut (Figure 11).

Based on an exploration of 38 examples of urban regions around the world, Forman (2008) reasserts some of the fundamentals already proposed by other planners of the early twentieth century, like Patrick Geddes, Fredrick Olmsted or Lewis Mumford. Such principles emerged from the need of restoring the interdependence between the urban

\footnotetext{
${ }^{7}$ Capitalism 1.0 is a first phase of capitalism system also known as free-market or 'laissez-faire', in which the politic power had a poor intervention; the interactions between governments and private companies were guided by the guarantee of military revenue and consequent protection of powerful interests. Some well-known facets of this period are the phenomenal economic growth, but also the cruel exploitation of workers and the environmental degradation. "... in the early capitalist era, land, resources, and places to dump wastes were abundant; aggregated capital was the scarcest factor. That's why rules and practices developed that put capital above all else." (Barnes 2006, p. 24)
} 


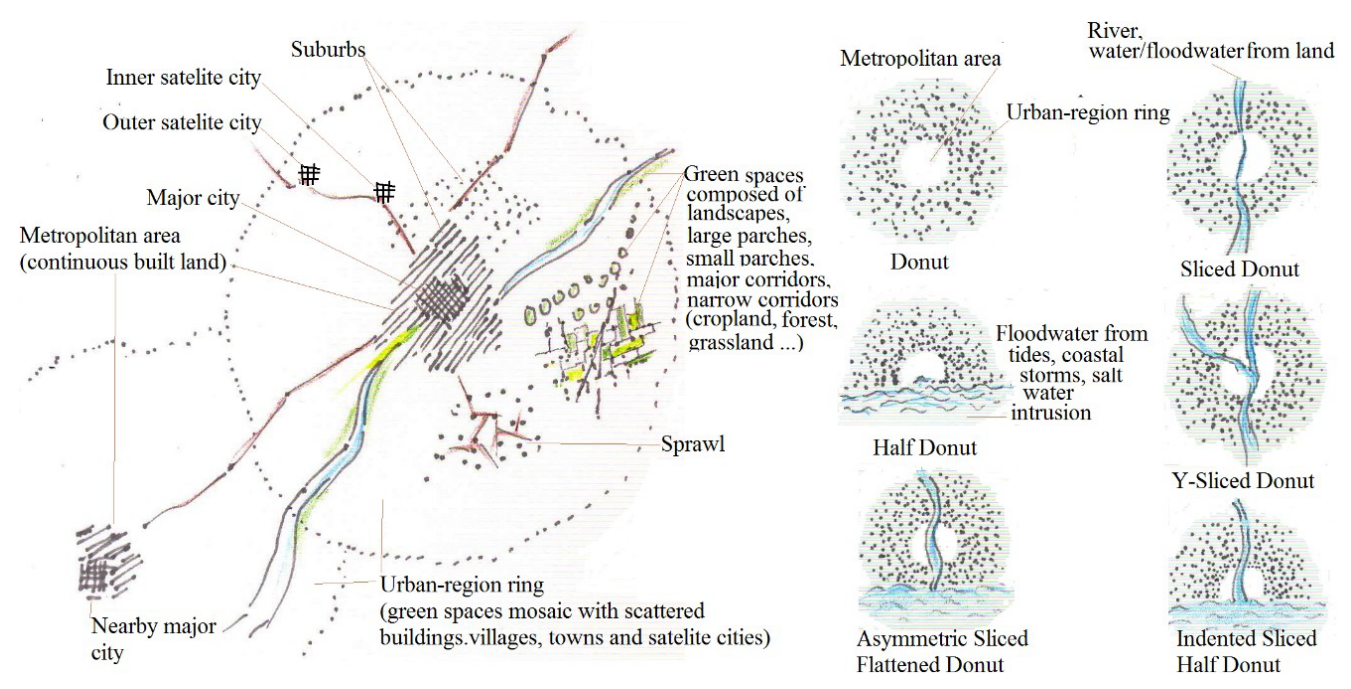

Source: Sketch by the author after Forman (2008).

Figure 11: Left: Concepts and terms for urban-regions; Right: Donut model

structure and the surrounding area that can support and feed the human settlements.

One can relate these concerns to the philosophical problem raised by Plato in the Timaeus, concerning the chôra. However, the unsustainable, even irreversible, state of big metropoles makes them the actual aporias, with no way out. Donadieu (2012), for example, states the unsustainable future of cities without close vicinity agriculture, thus inverting the aporias sense refused by Plato. This means that the future will depend on a third genus able to unify the matrix and the footprint of the existent human communities. In this sense, Donadieu conceives the 'Agropolia', an alternative urban world with agriculture and farmers, as a utopia similar to the urban-region proposed by Forman (2008).

\subsection{The Utopic landscape of the Algarve}

To this extent, the implementation of the urban world's existential vision in 'Agropolia' must explicitly reach two fundamental aspects. On the one hand, the perception of landscapes and places must be free from imposed cultural patterns, allowing their display as they are, understood and admired to get a satisfaction beyond the amorphous comfort and aesthetic pleasure of spectacles. On the other hand, the development of the sensitivity is crucial to resume the ties that bind people to the environment in which they live and to overcome the fetish choices inculcated by experts that stimulate consumption.

In physical terms, the description of this imaginary region is as follows, "Agropolia is not an island, but an archipelago of Urban Spaces built among the fields, parks, forests and ponds. There is a free access by railways and highways, through ports and airports. Beyond Agropolia, the ocean extends on one side and, on the opposite side there is a barrier of wooded mountains intersected by rural valleys sparsely populated." (Donadieu 2012, p. 285).

Such a description fits to the urban-touristic zone of Algarve (Figure 12), which is formally a polynuclear urban zone where we can identify the following basic components:

1. the donut hole of its urban region correspond to the continuous built mass formed by traditional urban centers and by urban settlements for tourism purposes;

2. the ring of the donut is the miscellaneous formed by urban sprawl, villages and little towns, green spaces (golf courses, wooded and agriculture areas, wetlands, etc.); and

3. the limit to the south is the Atlantic ocean and the northern boundary is formed by the shale mountains. 


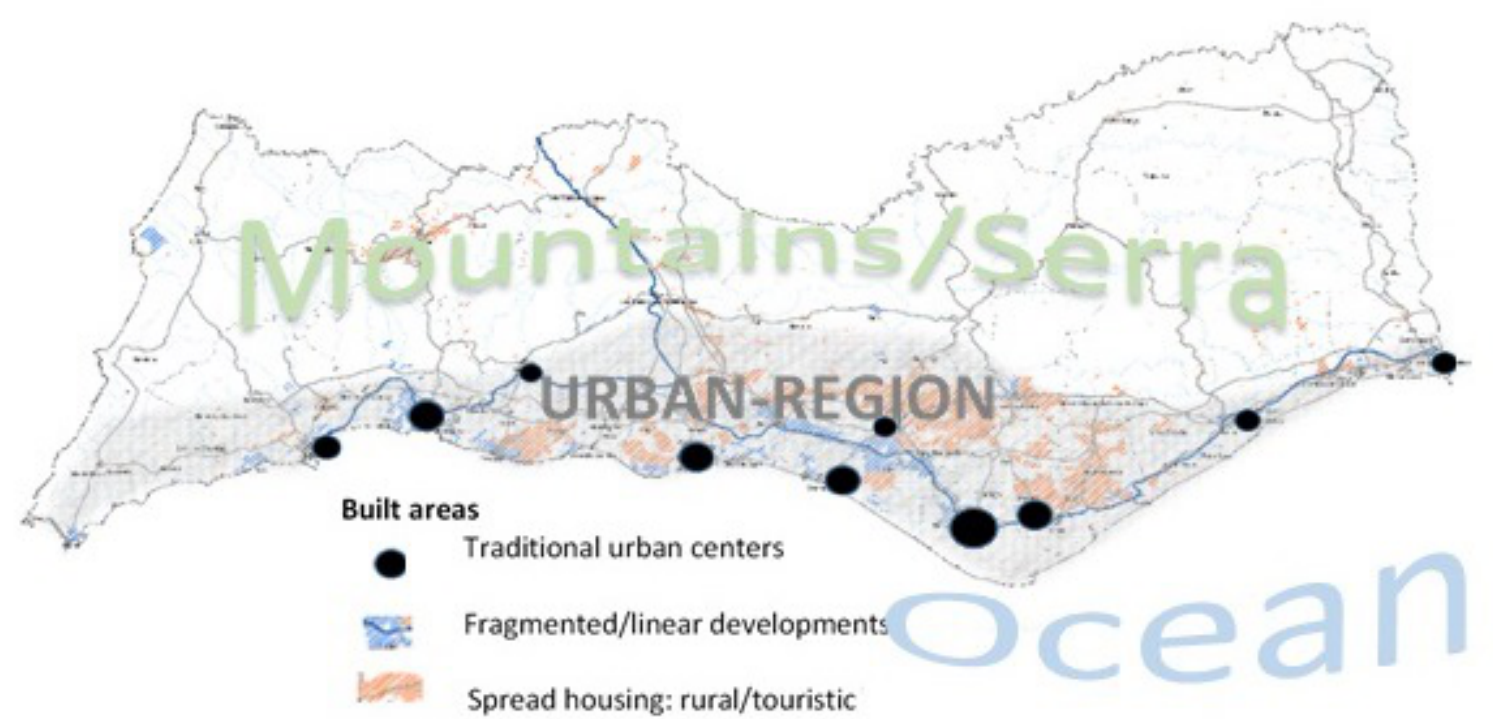

Source: Sketch by the author, no scale, using "peça gráfica 08, anexos volume 1" of the regional land management plan of Algarve (CCDRAlgarve. 2007)

Figure 12: The urban-region of Algarve. Main components and barriers; spectral zone

Undeniably, the coastal zone of the Algarve, as well as its background area has plenty of problems such as urban densification, bad locations, stressed sensible areas, aesthetic disharmony, etc. Nevertheless, the focus on this utopic urban-region may allow us an adequate scale for improving the actual situation, thus overcoming the management paradox and considering the landscape as the second half of the communities that live there. This perspective is quite different from that of landscape units. Our approach intends to look at landscape far from a closed entity that eventually achieves an optimal state to which one could compare and measure the impacts of human actions. Rather, we intent to reach an agreement about landscapes as special regions, once "... landscape descriptions are always biased. Furthermore, it is not possible to accurately define this bias, because there is no neutral ground from which a bias (or its extent) can objectively identified. In a relational view, however, (potential) biases can at least be put in a relation with each other and can be negotiated. As a consequence, landscape planning and development must be based on and geared towards negotiations of different trajectories and between different notions and stakeholders." (Backhaus 2011, p. 195).

\section{Rehabilitation and Renewal of Terraced Landscape}

It is under this perspective that we intend to prospect the future of dry walling as a structural element of landscape. Although we cannot witness a visual exuberance of the Algarve hills, the terrace frame, supported by the dry stone walling, can embody an aesthetical positive view for many perceptions. Furthermore, terraces are the base of an agrosystem with great ecological and cultural values. Hence, we try to reach the symbolic, aesthetic, cultural and ecologic values that the society needs to adopt.

The encouragement of public participation in a very effective way is crucial to prospect the ways for rehabilitation or renovation actions. Then, we need to support in a method that facilitates communication, to stimulate the citizen's participation in landscape evolution. In fact, there is a need to communicate perceptions and conceptions of landscapes as clearly as possible, in order to raise awareness and initiate processes of participation, and thus serve as a contribution to ethical discourse on landscape development (Hansen 2001). 


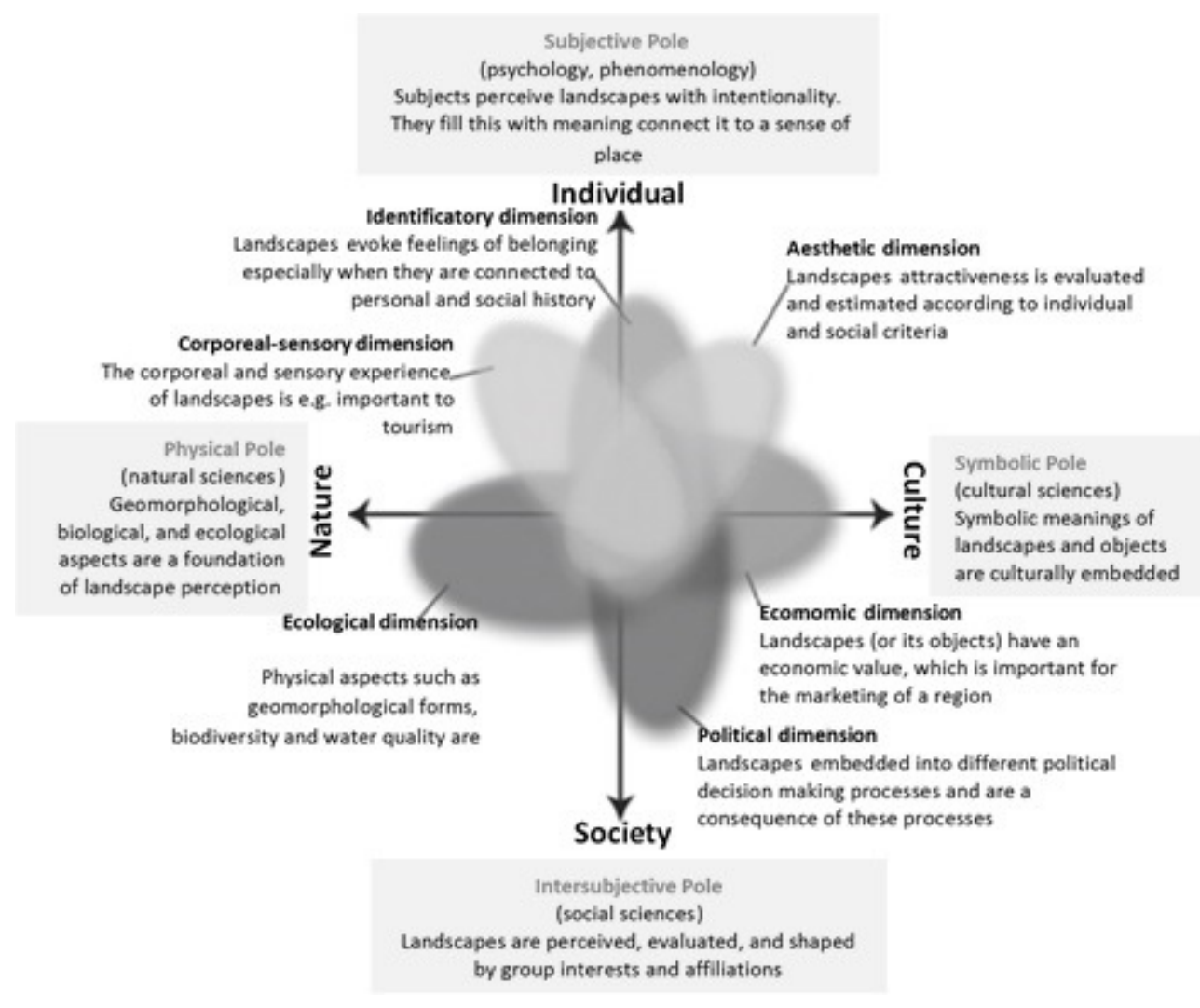

Source: Adapted from Backhaus (2011)

Figure 13: The four pole model with its six dimensions of landscape experience

\subsection{Explanatory model of landscape}

In that sense, we try to get closer to the guidelines of the explanatory model developed within the Swiss National Research Program 48 "Landscapes and Habitats of the Alps" (Backhaus et al. 2008), which includes a multidimensional approach, in which insights are shared and connected across the boundaries of disciplines. An important feature is to allow the location of different approaches of landscape perception.

The model's structure follows two main axes connecting four poles ${ }^{8}$. Once landscape perception and experience occurs between nature and culture, the first axe goes from nature to culture, because the role of landscape in mediating between the natural environment and human activity depends on acquired rules, models, and cultural patterns. The second axe goes from individual to society, because each individual has their own perception of the landscape as a part of a society that organizes and manages the space appropriated by different social groups. "The field that stretches between these four poles encompasses different kinds of approaches to and perceptions of landscapes. While every access to landscapes includes aspects of every pole, certain approaches tend to be drawn towards one or another pole." (Backhaus 2011, p. 196). Figure 13 sketches the two polarities and the six dimensions.

We then have four poles: physical, subjective, symbolic and intersubjective, which are described in detail below.

A) The physical pole refers to what people generally first perceive when beholding a landscape: arable land, rivers, woodlands, settlements, roads, animals, machines; however, landscape perception do not happen per se, in an 'objective' way, rather

\footnotetext{
${ }^{8}$ More than the three layers of landscape stated by Berque (1986), the biophysical, the subjective and the social, the model introduces a fourth layer or pole, considering cultural and intersubjective as separate poles. The main reason is to offer "... the possibility of better showing where the socio-cultural tensions, rifts, and disruptions are that determine landscapes today." (Backhaus et al. 2008, p. 134)
} 
resulting from different points of view. In fact, the natural flows and complex relations between living elements reveals the existence of many invisible or hidden aspects; the release or acknowledgement of such aspects may change the experience of beholders (Backhaus 2011).

B) The symbolic pole, at the opposite side of the axis, relates then with the cultural patterns, aesthetics and symbols that mediate people's perception and experience of the world and landscapes. Alterations of landscapes that oppose shared, often traditional, aesthetic notions are not easily accepted (Backhaus 2011). The art and media, for example, have an important role in transmitting patterns that are not merely instruments of perception but also systems of interpretation.

C) The subjective pole comprehends, on the one hand, the subject as the center of emotions, sensations and perceptions. Subjects intentionally grasp their surroundings using not only the visual sense but also all the other senses. On the other hand, this same pole also comprehends the subjects referred to as individuals within a society, individuals choosing the aspects of landscape that arouse their interest.

D) The intersubjective pole, at the opposite side of the axis, takes then into account the landscape as a product of social practices such as agriculture, trade, leisure, etc. Explicitly, landscape clearly involves economic factors such as the landscape as a resource with use value or market value, a sense of belonging and authenticity, a social history of representation, insiders and outsider's perspective, and political aspects like a political decision's impacts on landscape development.

We will explore some connections between these poles for the case of the Algarve urban region, as a way to detect some possible perceptions that can be useful for future discussions among stakeholders. In this sense, we expose some sketches used by Donadieu (2008) for terraced landscapes. Nevertheless, it will be necessary to pursue a more detailed fieldwork to explore the dimensions pointed by the four poles method and reach "... an ethical discourse that includes a mandate for the protection and shaping of landscapes" (Backhaus et al. 2008).

\subsection{Main trends and possible evolutionary prospects}

Following the Donadieu (2008) scheme, we point out two trends more or less pursued: the abandonment and the conservation of functionality. The abandonment, which occurs in most cases, has to do, on the one hand with the rural exodus to the cities and tourist centers and, on the other hand, the difficulties of modernization and agricultural techniques due to steep slopes, cost of hand labor, marketing alternatives. The conservation of functionality, increasingly less frequent, may be related with the Common Agricultural Policy (CAP) aids to subsistence agriculture, but also with maintained activity by traditional farmers, or even modern farmers in the case of some farms being economically sustainable.

At this point, we must search for three alternatives. Firstly, we may think about assigning a patrimonial value to terrace landscapes, under a statute of cultural landscapes. In such a situation, these landscapes are likely to fall into oblivion, 'collective amnesia', or stay as a souvenir object, 'anamnesis'. It might even happen through classification as world heritage sites, or inclusion in museum figurines of planet cultures.

Therefore, as a second possibility, it might be necessary to place landscapes into value through the image, i.e. by aestheticizing them, even if such landscapes do not exhibit any special attributes. This would occur within tourism interests, by artializing the landscape (Roger 1997) via image and text descriptions, then creating beauty, excitement and spectacle. With fewer chances, we would consider an enhancement through agricultural economy, shaping the landscape in order to make it more attractive, not only for the 'excellency' of the products obtained, but also for the aesthetics.

As a third possibility, one can consider to recover abandoned terraces or even to create new platforms. For the barrocal of the Algarve, we could think about unique branded goods such as 'unique Algarve orange', famous Silves fig, etc., like the Oporto vineyards in the north of Portugal or the Cassis vineyards in France. In a touristic environment like 


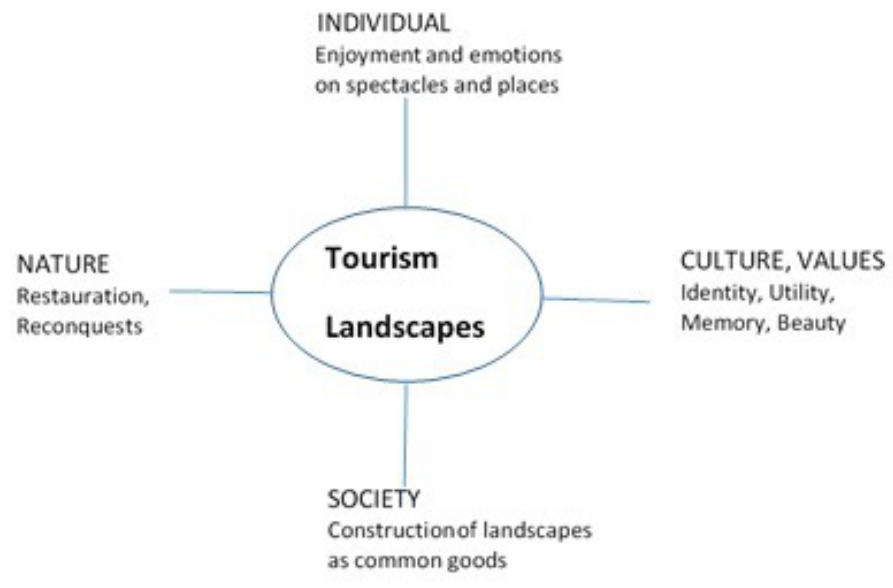

Source: Adapted from: Backhaus et al. (2008) and Donadieu (2008)

Figure 14: The four pole model for tourism landscapes

the Algarve, the promotion of cultural and tourist circuits could be more plausible; once a change from linear developments to non-linear ones is not expected, a combination of several solutions would be necessary.

In short, we can have the following typologies: 1) landscapes of abandonment and 'oblivion'; 2) patrimonial landscapes or 'collective memory'; 3) cultural landscapes promoted by recognition/artialization of unique places, notable, or even common places 4) highly valued landscapes of individual economic profitability; 5) landscapes of 'reconquest', including the addition of types $2+3+4$.

\subsection{Tourism landscapes}

Once tourism is the driving force of the Algarve land planning, the attraction for the future fate of this region will be to embrace the dynamics of tourism landscapes. Then, the main goal of the intersubjective strategy for the urban region, in which the barrocal is the 'living' part (ecologically speaking), lead by the interest groups linked to tourism, will be the construction of landscapes as common goods (Figure 14). Taking the other sense of the axis, the framework of individual perceptions of enjoyment and emotions on spectacles and places will conform the societal strategy of building the landscape as a common good, prejudging the individual demands of enjoyment and excitement. Therefore, rehabilitation and 'reconquest' should respect the cultural features and identity values that invoke collective memory and convey beauty.

When looking for practical possibilities of recovery, restoration or 'reconquest', a key question one should put, drawing inspiration from Neuray (1992), is to know exactly who the recipients of these landscapes are. It will be then imperative to take into account the various ways of looking at the landscape, within different sensitivities, learning and training. In that sense, Donadieu (2008) considers landscapes as:

1. The perceptions / 'looks' trained in relation to the beauty and landscape art, aestheticians, outsiders, exogenous, including here most of the tourists;

2. The initiated looks in relation to the rules of local life, which will be insiders, endogenous, including here much of the urban population;

3. The perceptions / 'looks' informed by material and immaterial production of landscapes, corresponding to scientific looks.

This does not mean that every way of looking corresponds to a specific type of local landscape, although some landscapes will appeal more to certain ways of looking than others. For example, the trained 'looks', usually attributed to tourists, tend to value 


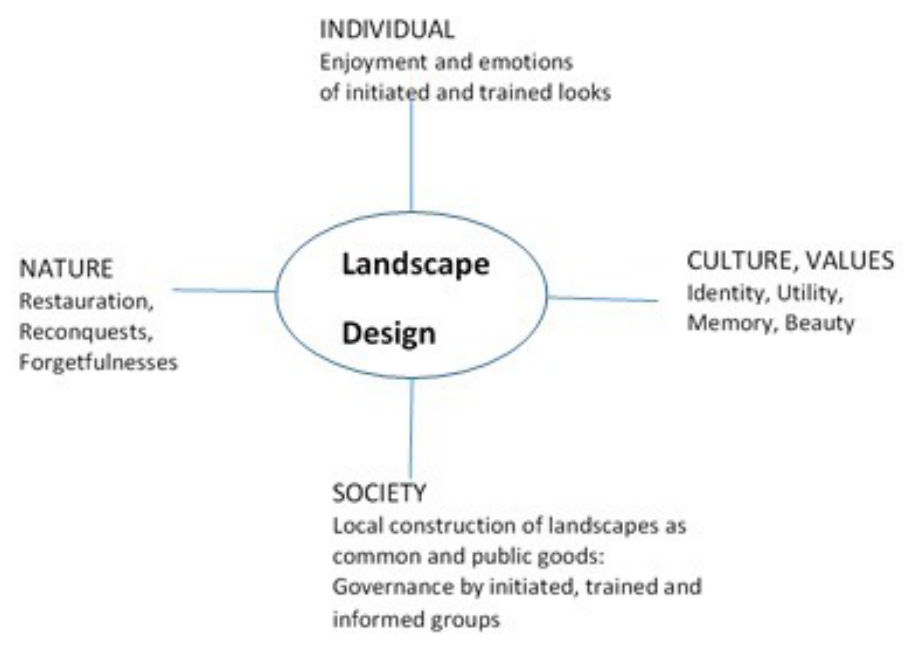

Source: Adapted from: Backhaus et al. (2008) and Donadieu (2008)

Figure 15: The four pole model for landscape design

scenarios with more formal splendor and contrasts - Machu Pichu in Peru, the rice field terraces in Asia, the Portuguese Douro valley vineyards, etc. However, a landscape with an impressive visual effect over a traditional compact city will have similar valuations by many trained looks from tourists, initiated looks from urbanites and farmers, and informed looks from agronomists, biologists, architects, landscape architects, etc.

Therefore, the local construction of landscape, sketched and promoted on a regional scale, will require a shared governance between initiated, trained and informed social groups. Taking the spectrum of the vertical axis (Figure 15), the individual perceptions based on the enjoyment and emotions of initiated and trained looks will integrate the intersubjective construction of local landscapes as common and public goods. The satisfaction of the various looks that will contemplate such planned landscapes must necessarily take into account the cultural values -identity, utility, beauty and memory. This will influence the several typologies of resulting local landscapes, according to the natural conditions under such cultural features; one must concretely think about designing local landscapes that can be rehabilitated or regained and, at the same time, imbalance those that will be forgotten, such as patrimony and 'collective amnesia'.

\subsection{Landscape's governance}

Then the following crucial question is about the real terms of governance to implement. According to Donadieu (2008), in the current situation, one can consider three essential facets:

1. The legislative injunction, top-down arising from the European Landscape Convention and the respective transpositions into national legislation;

2. The self-sustainable local initiatives (Magnaghi 2000), bottom-up;

3. The local governance landscape projects, bottom-up and top-down.

As for the legislative injunction, one can recall, for example, some articles of the European Landscape Convention:

- $\operatorname{art}^{\mathrm{o}} 1$ a) [Landscape] “... an area, as perceived by people, ...";

- $\operatorname{art}^{\circ} 1$ b) "'Landscape quality objective" means, for a specific landscape, the formulation by the competent authorities of the aspirations of the public ...";

- $\operatorname{art}^{\mathrm{o}} 6 \mathrm{c}$ ) "Identification and assessment" 1 "With the active participation of the interested parties ...". 


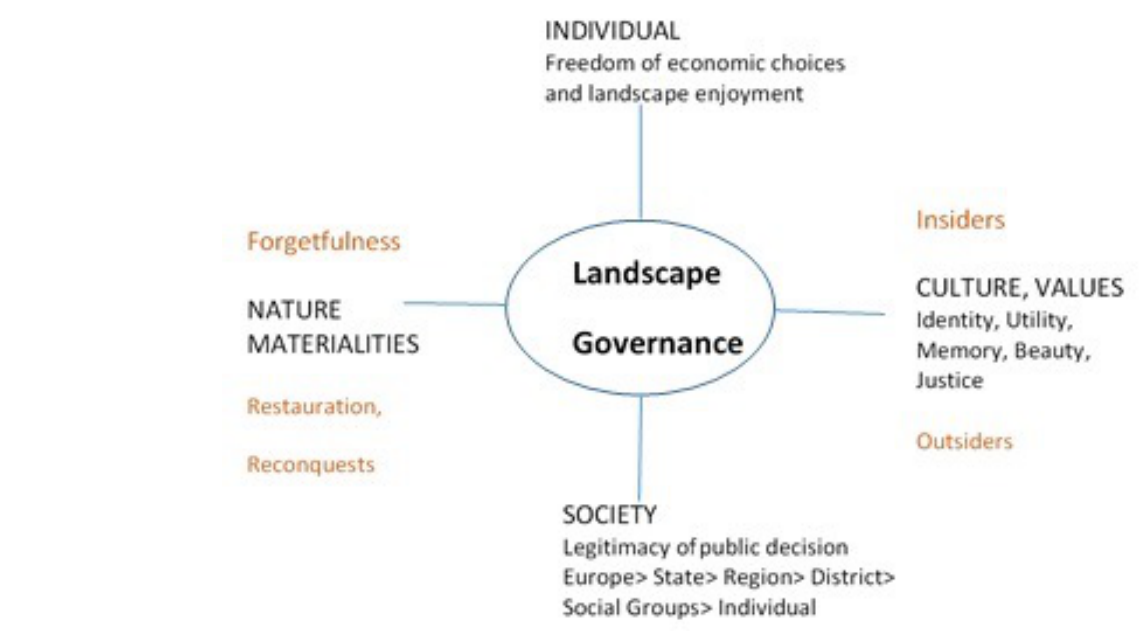

Source: Adapted from: Backhaus et al. (2008) and Donadieu (2008)

Figure 16: The four pole model for landscape governance

The influence of public authorities on modeling the perception and the formulation of the aspiration of the public can easily happen, despite the call for the active participation of interested parties. In fact, for the Algarve region, we have detected many problems in terms of active public participation (Bragança 2006). Here the top-down practices prevailed in the conventional land planning and management processes, once decision-making fulfils a legitimacy ritual based on descending disclosure of information, consultation and conciliation attempt.

As a typical example of top-down governance for terraced landscapes, Donadieu (2008) mentions George Brassens Public Park in Paris, recreating terraced vineyards of XIX century, with non-commercial purposes. Similarly, it is easy to imagine a decision -from the central or local authorities- about the reuse of some terraced dry orchard of Algarve's barrocal as merely recreational areas aesthetically designed for satisfying coastal urbanites and mass tourism.

Bottom-up governance implies a delegation of decisions to local communities, which have the autonomy and the chance to pursue a participatory local democracy. Hobby farming can provide some examples in this case. For the Algarve urban region one could imagine some associative initiatives of urban citizens that live in coastal cities, forming communities whose aim would be to enjoy farming on barrocal, thus reactivating traditional practices similar to permaculture. They would buy or rent some properties and explore the dry orchard products mainly for personal needs, including the conservation of their cultural identity.

Merging top-down and bottom-up implies to interchange information, co-decision making and involvement in management. It can be the case of some projects promoted by local or regional institutions satisfying the ambitions of local representative agents or communities, who actively collaborate in the promotion and continuity of such projects. One might imagine a project for promoting the 'Algarvian' almond or carob as products of excellence, unique, designed by the regional university and prioritized by the regional authorities, as the result of the lobbying exercised by a significant group of farmers and other social agents who are conscious of real dry orchards value. Such a project could easily take advantage of the possibilities provided by EU funds.

The options about the arrangement for landscape governance will derive from individual freedom of economic choices, framed by the legitimacy of public decisions (Figure 16). The cultural values of identity, utility, collective memory, beauty and justice guide the options for the management of physical, biophysical, material reality. Such values closely relate to the ethical patterns ${ }^{9}$ of insiders and outsiders that can reinforce the restoration,

\footnotetext{
${ }^{9}$ As noted by Hansen (2001, p. 247): "Ethical norms are usually associated with what values are to be realised." Moreover, "To value something is to make moral decisions, and moral decisions build on ethical
} 
'reconquest' and/or forgetfulness of local landscapes.

The restauration and renewal of dry stone walling structure will depend on numerous options sketched using the landscape as an instrument of knowledge and acknowledgement of the regional space. Even considering tourism landscape, our focus on the urban-touristic region of Algarve enhances the landscape as a common good. To that extent, one must overcome the nostalgic statement and try to redevelop landscape as a viable locus of a modern way of life (Fontanari 2008). Then, the looks of insiders and outsiders will condition the aesthetic features of regional landscape design, taking into account that "the principles derived from the recognized aesthetic values embodied by terraced landscape should be applied in the construction of new landscapes of which terraces are a crucial central component." (Fontanari 2008, p. 12), once "local communities have certain "rights" over such local assets." (Fontanari, Patassini 2008, p. 7). The three main types of local units that may emerge from designing the regional landscape are: 1) restoration; 2) 'reconquest' and 3) forgetfulness. They all entail governance systems derived from the negotiations between different notions and stakeholders; however, the bottom-up and mixed bottom-up and top-down styles seems to be more adapted to manage the future landscape.

\section{Final Remarks}

We actually follow a process of evolution in landscape policies that requires changes at social, cultural and individual levels (Backhaus et al. 2008). It is not easy to overcome the dualistic matrix that conditions the Western way of thinking and acting. In a progressive way, however, the current changes leads to incorporating more intangible aspects on landscape design and development. By rejecting the actual aporias of unsustainable cities and metropolitan areas, design processes necessarily face us with realistic utopias, both at local/regional levels and globally. As suggested by Forman (2008), we even can take 'big pictures', global sustainable scenarios, into account: "Think Globally, Plan Regionally, and Then Act Locally. Keep the globe in mind when making daily decisions. But most importantly, create a plan for every landscape and every region that provides sustainably for nature and people. Then with the broad plan in hand, make the important local changes and refinements that fit effectively into the big picture." (Forman 2008, p. 317).

In the case of the Algarve urban region, which hallmark was its terraced landscape supported by a dry stone walling structure, the first step will be an effective knowledge of its physical presence and significance. For the physical aspects, we mean extension, adaptation to topography, forms and aesthetic combinations; for the significance, we mean symbolic, technological, ecological, economic values. Such aspects received a poor attention from the public institutions responsible for land planning and management, despite the cascade of plans that emerged in the last three decades. A second step will be to pave the way for more democratic forms of governance, bottom-up or merged top-down and bottom-up, encouraging collective actions or concerted design projects, thus overcoming the typical top-down mechanisms of conventional plans.

Unless the dry stone walling structure of the Algarve becomes part of a patrimonial set of the Mediterranean typical coastal landscapes, the lack of its spectacular appearance surely make difficult its recognition as a world heritage. This does not detract the importance of strengthing its cultural value by the people that coexist in this landscapes. In view of actual interest groups, it appears plausible that tourism can provide a valuable support towards an 'artialization' (Roger 1997), thus enhancing all symbolic values and making patrimonial value easier to be recognized. In that sense, many looks must be initiated, particularly among urbanites. It will then be possible to rehabilitate and renew a large part of dry stone walling of the Algarve urban-tourist region, despite the difficulty from learning how to forget and to reassign new values to the landscape that may display new narratives and enhance its poetry (Nohl 2001).

considerations. ... By involving the public in general together with different types of experts and those who live in the landscapes in question, or who use them in different ways, these different groups will have opportunities to influence the ethical discourse by reasonable arguments." (Hansen 2001, p. 252). 


\section{References}

Antão T (2010) O espaço de habitar vernacular no barrocal algarvio. Master's thesis. departamento de arquitetura. escola de artes. universidade de Évora.

Antrop M (1999) Background concepts for integrated landscape analysis. Agriculture, Ecosystems and Environment 77: 17-28. CrossRef.

Asins-Velis S (2006) Linking historical mediterranean terraces with water catchment, harvesting and distribution structures. In: Morel JP, Jordi J, Matamala J (eds), The archaeology of crop fields and gardens. Edipuglia s.r.1., Barcelona, 21-40

Backhaus N (2011) Landscapes, spatial totalities or special regions? Procedia Social and Behavior Sciences 14: 193-202. CrossRef.

Backhaus N, Reichler C, Stremlow M (2008) Conceptualizing landscape: An evidencebased model with political implications. Mountain Research and Development 28[2]: 132-139. CrossRef.

Barnes P (2006) Capitalism 3.0 - Guide to reclaiming the commons. Berrett-Koehler Publishers, Inc., San Francisco

Barão M (2014) Linhas de água (re)construídas no barrocal algarvio. Sistemas de reaproveitamento de água de nascente para rega e moagem. master's thesis. departamento de artes e humanidades. faculdade de ciências humanas e sociais. universidade do algarve.

Berque A (1986) Le sauvage et l'artifice - Les Japonais devant la nature. Gallimard, Paris

Berque A (2012) La chôra chez platon. Em t. p. (dir.), espace et lieu dans la pensée occidentale de platon à nietzche (pp. 13-27). la découverte. paris. what is this?

Berque A (2013) Tétralemme et milieu humain : la mésologie à la lumière de yamauchi. Ebisu 49: 57-71. CrossRef.

Bragança C (2006) Metodología para la evaluación de sistemas territoriales. aplicación al sistema hidrológico-hidráulico del algarve. Ph.d. thesis. departamento de geografía humana. facultad de geografía e história. universidad de sevilla

Braudel F (2001) Memórias do Mediterrâneo. Pré-história e Antiguidade. Terramar, Lisbon

Brisson L (1998) Le même et l'autre dans la structure ontologique du Timée de Platon. Academia Verlag, Sankt Augustin

CCDRAlgarve. (2007) Plano regional de ordenamento do território do algarve. Acceded in 24 of february 2017 on the web site of comissão de coordenação e desenvolvimento regional do algarve: http://www.prot.ccdr-alg.pt/download.aspx

Colas AS (2009) Mécanique des murs de soutènement en pierre sèche: modélisation par le calcul à la rupture et expérimentation échelle 1. Ph.d. thesis. École centrale de lyon. université de lyon

Contessa V (2014) Terraced landscapes in italy: state of the art and future challenges. Master's thesis. dipartamento territorio e sistemi agro-forestali. università degli studi di padova

Costa E, Brites J, Pedrosa M, Silva A (1985) Carta hidrogeologica da orla algarvia. Serviços Geológicos de Portugal, Lisbon

Descazeaud M, Faraggi T, Soulage J (2014) Murs de soutenement - comparaison environnementale et financière de différentes technologies. École centrale lyon 
Donadieu P (2008) Terraced landscapes in europe: Why, for whom and how? Alpter final conference. ljubljana. acceded in 24 of june 2015 on the web site of alpter project: http://www.alpter.net/img/pdf/2 ${ }^{\prime}$ donadieu'ljubljana'07.pdf

Donadieu P (2012) As paisagens agriurbanas: uma utopia realista? In: Veríssimo Serrão A (ed), Filosofia e Arquitetura da paisagem. Um manual. Centro de Filosofia da Universidade de Lisboa, Lisbon

Feio M (1983) Le Bas Alentejo et l'Algarve. Centro de Ecologia Aplicada da Universidade de Évora, Évora

Fontanari E (2008) A move beyond nostalgia. In: Fontanari E, Patassini D (eds), Terraced Landscapes of the Alps. Projects in progress. Marsilio Editori, Venice, 10-13

Fontanari E, Patassini D (2008) Introduction. In: Fontanari E, Patassini D (eds), Terraced Landscapes of the Alps. Projects in progress. Marsilio Editori, Venice, 7

Forman R (1995) Land Mosaics: The Ecology of Landscapes and Regions. Cambridge University Press, New York

Forman R (2008) Urban Regions. Ecology and Planning Beyond the City. Cambridge University Press, New York

Foster BG (2004) Terraces and terracing. Encyclopedia of soils in the environment 4: 135-143

Guerny J, Hsu L (2010) Terraced landscapes: Meeting to challenges to sustainability. A nothern mediterranean agriculture perspective. first terraced landscape conference. honghe, china

Hansen B (2001) Ethics and landscape: Values and choices. Ethics, Place and Environment 4[3]: 246-252

Kalaora B (1998) Au-delà de la nature, l'environnement. L'observation sociale de l'environnement. L'Harmattan, Paris

Larcena D (2012) Terrasses et eau des versants en méditerranée; dynamiques Écologiques et Économiques. In: Aspe C (ed), De L'eau Agricole À L'eau Environnementale. Résistence et Adaptation Aux Noveaux Enjeux de Partage de L'eau En Méditerranée. Éditions Quae, Versailles, 241-252

Lasanta T, Arnáez J, Flaño P, Monreal N (2013) Los bancales en las montañas españolas: un paysaje abandonado y un recurso potencial. Boletín de la asociación de geógrafos españoles 63: 301-322

Machado J (1991) Grande Dicionário da Língua Portuguesa. Publicações Alfa

Magnaghi A (2000) Il progetto locale. Bollati Boringhieri, Torino

Martini S, Pesce G, De Franchi R, Colombo R, Tavaroli F (2004) Manuale per la construzioni dei muri a secco. linee guida per la manutenzione dei terrazzamenti delle cinque terre. http://www.alpter.net/img/pdf/manuale recupero.pdf

Naredo J (1982) La ordenación del territorio: sus presupuestos y perspectivas en la actual crisis de civilización. Cursos de ordenación del territorio. madrid

Neuray G (1992) Des paysages. Pour qui?. Pourquoi?. Comment? Les presses agronomiques de Gembloux, Gembloux

Nohl W (2001) Sustainable landscape use and aesthetic perception-preliminary reflections on future landscape aesthetics. Landscape and Urban Planning 54: 223-237. CrossRef.

Oteros J (2014) Modelización del ciclo fenológico reproductor del olivo. Ph.d. thesis. servicio de publicaciones de la universidad de córdoba 
Petrella R (1996) Le Bien commun. Éloge de la solidarité

Reynès A (2000) Patrimoni de marjades a la mediterrania occidental. una proposta de catalogacio. Technical report, Mallorca

Roger A (1997) Court Trâ̂té de Paysage. Gallimard, Paris

Seva E, Román J, Seva R (2005) El origen prehistórico de los bancales/borda como habitación y refugio ganadero en la montaña de Alicante (España). Mediterranea. Série de estudios biológicos 18: 8-50

Telles G (1998) Paisagem global. In: Pinto-Correia T, Cancela de Abreu M (eds), Challenges for Mediterranean landscape ecology: the future of cultural landscapes examples from the Alentejo region: proceedings of the 1st national worshop of landscape ecology. APEP - Portuguese Association for Landscape Ecology, Montemor-o-Novo

Varotto M (2008) Towards the rediscovery of the "middle landscapes". In: Scaramellini G, Varotto M (eds), Terraced landscapes of the Alps. Marsilio, Venice, 112-117

Villemus B (2004) Étude des murs de soutenement en maçonnerie et pierres seches. PhD Thesis, Institut National des Sciences Appliquées de Lyon. Université de Lyon

Watsuji T (2011) Fūdo, le milieu humain. CNRS, Paris. Originally published 1935 (CC BY NC) license (http://creativecommons.org/licenses/by-nc/4.0/). 